\title{
Transcending Institutionalized Islām, Approaching Diversity: ‘Abdelmağīd Šarfī’s Conception of a Qur'ānic Ethics of Liberation
}

\author{
Tina Dransfeldt
}

\begin{abstract}
This article engages with the intellectual enterprise of Tunisian Professor Emeritus in Arab Civilization and Islamic Thought, 'Abdelmağīd Šarfí. Šarfì is one among many Arab intellectuals who have engaged in a critical reading of the Qur'ān and the Islamic tradition in order to challenge the traditional Islamic disciplines and methodologies. Through his reading of the prophetic message as discourse rather than text, his interpretation of 'the seal of the prophets', and his conception of a Qur'anic ethics of liberation, this article intend to discuss the difference between an engaged historical criticism, such as Šarfi's, and the common conception of reformist Islām.
\end{abstract}

When reformist Islamic thought (al-fikr al-iṣlāhi $)$ is the subject of research in the West, the difference between the former and academic research, carried out by scholars with Muslim background, is often confused. Contemporary scholars from the Muslim world who work within the field of Islamic Studies are often labeled 'reformists' if the subject of their research is the relationship between the Islamic tradition (turāt ) and modernity. ${ }^{1}$ The Algerian professor in Islamic Studies, Muhammad Arkoun (1928-2010), has addressed this issue on several occasions as he himself has often been labeled a representative of modern reformist Islām, despite his efforts to deconstruct the mythological and ideological nature of what he calls the "Islamic

\footnotetext{
${ }^{1}$ Rather than merely reading their works in the context of recent intellectual developments in the Muslim world, Carool Kersten argues in a similar vein, in Cosmopolitans and Heretics: New Muslim Intellectuals and the Study of Isläm (2011), that there is a huge potential in studying the methodological, epistemological and philosophical underpinnings of their work, which, according to him, "can actually contribute to redefining a field of scholarly inquiry where the rules of engagement are still predominantly determined by Western academe." (Kersten 2011: 6). Examples of valuable studies, which, however, focus primarily on the social and political implications of their work (i.e. their reformist potential) rather than engaging in a dialogue with them about the epistemological and methodological premises of Islamic Studies, are: Leonard Binder, Islamic Liberalism: A Critique of Development Ideologies (1988), Robert Lee, Overcoming Tradition and Modernity: The Search for Islamic Authenticity (1997), and Ibrahīm M. Abu-Rabī', Contemporary Arab Thought, Studies in post-1967 Arab Intellectual History (2003), to mention but a few.
} 
reason' (al- 'aql al-islāmī):

Far from suggesting that there is such a thing as a generically 'Islamic' reason, let alone advocating its claims, the treatise [Towards a critique of Islamic Reason] was intended to show how such a mythical construct could arise, and to demonstrate the advantages of probing it by means of the critical tools of modern linguistic, anthropological and historical scholarship. It was dismaying to find, therefore, scholars such as Leonard Binder or (to a lesser degree) Robert Lee or Olivier Carré and others who have commented on my work, evidently failing to grasp the radicalism of my intent, took my work as a species of modern, reformist (islāhì) Islām; whereas, in my whole approach, Islamic 'reform' of the familiar type, represents precisely the kind of mythologising and ideologising that I am concerned to lay bare and to help overcome. (Arkoun 2006: 10f.)

Rather than advocating a reform of 'Islamic reason', Arkoun proposes that Islām, both in its historical and its contemporary manifestations, is studied by means of a historical epistemology. Contrary to the descriptive and narrative presentations of classical historiography, the objective of the progressive-regressive method of Arkoun's historical epistemology is to identify the ideological and mythological nature of so-called 'Islamic reason' and so-called 'Western reason' (cf. for instance Arkoun 2005: chapter 3, or Arkoun 2006: 16f., 219f.). The regressive process, on the one hand, is a process of looking back at the past, not to find a sacred and mythic past which can help reactivate sacred, uncontaminated and universal 'values', but to deconstruct turāt and the canonized corpus of religious texts, which have been used - and are still being used - to maintain monolithic conceptions of Islām. That is, the regressive process is an archaeological cognitive project through which it is possible to identify the historical epistemologies, which prevailed in each given historical context without projecting back 'modern' criteria and value judgments. The objective of the progressive process, on the other hand, is to liberate contemporary Islamic thought from "obvious, heavily ideological, mythological manipulations of the dismantled collective memories in the present context of modernization and globalization." (ibid: 219). The aim of the progressive-regressive method is to uncover the past in order to construct the future:

This critical inquiry is also designed to contribute to the programme of emerging reason, namely, providing our present thinking with a new dynamic, more relevant intellectual tools and flexible procedures that are constantly being revised, reappropriated theoretical frameworks to reassess on more reliable basis, the articulation of authority and power. (ibid: 219f.) 
Contrary to the Orientalist discourse, which insists on 'neutrality' in regard to the studied object (cf. for instance the quote by Roger Arnaldez below), Arkoun advocates an engaged historical enterprise with a progressive perspective. The Orientalist's alleged neutral and objective approach to turāt contributes, according to Arkoun, to the maintenance of the ideological and mythological construct 'Islām' which he seeks to subvert.

Thus, I would argue that there are two aspects of this engaged historical criticism, which are important here. Firstly, uncovering the past in order to construct the future forms an integral part of the poststructuralist epistemology that scholars, such as Arkoun, rely on. According to these scholars, meaning and knowledge is socially constructed, and it is imperative to them that this is acknowledged as they seek to challenge any essentialist conception of both Islām and the West. As such, they are engaged in an academic debate about the proper epistemological and methodological approach to the field of Islamic Studies. Secondly, the progressive perspective indirectly points to the fact that these scholars also operate as intellectuals who are engaged in the public debate, and whose insistence on the need to renew Islamic thought is dedicated to advocating human rights, individual liberty and democracy. In this respect their work could be understood as prescriptive in a way comparable to that of reformists and revivalists. However, contrary to the latter they do not claim to hold any one, true interpretation of Islām, they simply insist on absolute freedom to research their religious heritage.

Whereas many studies have been dedicated to the latter perspective ${ }^{2}$ this article addresses the former in its interconnection with the latter. In the following, I will discuss how this progressiveregressive method is reflected in the historical-critical work of the Tunisian Professor Emeritus of Arab Civilization and Islamic Thought, 'Abdelmağìd Šarfī (b. 1942), who has also first and foremost been studied as a representative of 'reformist Islām'. ${ }^{3}$ I will start with a clarification of the difference between the critically engaged enterprise of intellectuals, such as Arkoun and Šarfì, and the common conception of modern 'reformist' Islām. Then I will analyze the implications of Šarfī's discourse analysis of the prophetic message and the subsequent reception of the latter. I will conclude with a discussion of his conception of a Qur'ānic ethics and its relation to 'reformist Islām'.

\section{Enlightened Muslim Thought}

As both Orientalists and traditionalists have identified Islām with the

\footnotetext{
${ }^{2}$ Cf. note 1.

${ }^{3}$ Cf. for instance R. Benzine's chapter on 'Abdelmağīd Šarfì in Les nouveaux penseurs de l'Islām (2004).
} 
canonized tradition and argued that any 'objective' study of Islām must be in accordance with this tradition, it has become necessary for scholars in the field of Islamic Studies to argue for the compatibility of Islām and modern scientific methodology. ${ }^{4}$ According to the French Orientalist Roger Arnaldez, for instance, modern theory of science is incompatible with the study of Islām:

Qu'un Islamologue ait une réaction personelle devant l'Islām, c'est ce qu'on ne saurait lui interdire. Qu'il étudie des textes, cela est indispensable et ne saurait être trop recommandé en dépit de leur nombre et de leur volume imposants, ainsi que des difficultés de la langue arabe. Mais il doit se garder d'interpréter ces textes à sa manière, fût-ce au nom de ce qu'il considérerait comme une méthode scientifique. Par exemple, il pourrait être tenté de traduire un verset coranique en s'appuyant sur la linguistique la plus moderne, sur la philology sémitique la plus éprouvée, et la critique historique la plus exigeante; mais si, par ces procédés scientifiques, il donne à ce verset un sens qu'aucun commentateur musulman n'a reconnu, il ne fait pas œuvre d'Islamologue. (Arnaldez 2002: 7f.)

(We cannot prohibit an Islamologist from having a personal relation to Islām. It is essential that he studies the texts, and this cannot be recommended enough despite their number and their impressive volume, as well as the difficulties in respect to the Arabic language. But he must resist from interpreting these texts in his own way, even if it is in the name of something he would consider a scientific method. He might, for example, be tempted to translate a Qur'ānic verse while relying on the most modern linguistics, the most proven Semitic philology and the most rigorous historical criticism; but if he, through these scientific methods, gives the verse a meaning which no Muslim commentator has recognized, it is not a work of an Islamologist.)

By claiming that the only legitimate manifestation of Islām is the canonized tradition, arguments like this do not only disqualify any critical study of the Qur'ān and the Islamic tradition, it places scholars in the field of Islamic Studies with Muslim background, who rely on a poststructuralist methodology in their research, in "a personal relation

\footnotetext{
${ }^{4}$ It is rather the rule than the exception that these scholars introduce their works with a discussion of the proper epistemological and methodological approach to the field of Islamic Studies in order to address those critics who have questioned the legitimacy of applying modern scientific methodology in the study of Islām, be it Western scholars, such as Roger Arnaldez, or the 'ulam $\bar{a}$ ' who maintain that only the traditional Islamic disciplines should be applied in the interpretation of the Qur'ān and the Sunna. It is my contention that these reflections are often mistakenly read as an expression of 'reformism' rather than as an expression of academic positioning.
} 
to Islām" deemed subjective or reformist rather than scientific. These scholars unquestionably do have "a personal relation to Islām". Disqualifying critical research, regardless of whether the research is being conducted by Muslims or non-Muslims, by claiming that the application of, for instance, historical criticism reveals a "personal relation to Islām" is problematic. One must ask: Is it even possible to have two antithetical approaches to a research field, such as the history of ideas - one for Western thought, where poststructuralist methodology is legitimate, and one for Arab-Islamic thought, where it is not?

In order to counter arguments like Arnaldez', scholars in the field of Islamic Studies have felt obligated to argue for the legitimacy of poststructuralist criticism in the study of Islām, and it is my contention that this should be acknowledged as part of an academic debate about the proper epistemological and methodological approach to the field of Islamic Studies, and not be confused with the reformist aspects of their intellectual enterprise. As Arkoun rightly argues, this is not an expression of an 'Islamic 'reform' of the familiar type". I will define this 'reform' more precisely in the following.

Since the nahda period (19th to early 20th century), Modern Arab-Islamic thought has developed out of a confrontation and meeting with Europe as an intellectual capacity and a rising power.

From its beginning, modernity has been double-edged: it contained within it both creative, scientific, and exploitative dimensions. In addition to representing rationalism, discovery, and the systematization of disciplines, modernity represents encounter, domination, and exploitation. (Abu-Rabi`2003: xv)

Because of this equivocal nature of modernity, the Arab intelligentsia has vacillated between fascination with and hostility towards the technological and scientific achievements of the West. Modern Arab-Islamic culture has been characterized by an ongoing conflict between authenticity (așāla) and modernity (hadāta), between returning to its roots $(u s ̦ \bar{u} l)$ or accepting the cultural and scientific achievements of the West. Whereas the reformists of the 19th and early 20th century acknowledged the need to renew (tağdìd) Islamic thought and the established disciplines, their approach to the relation between Islām and modernity was somewhat apologetic as they sought to defend Islām against Western and Orientalist claims that Muslim societies were incapable of adapting to modernity. The so-called 'founding fathers' of modern reformism - Ğamāl al-Din alAfḡān̄i (1839-97) and Mūhammād 'Abduh (1849-1905) - were therefore preoccupied with arguing for the compatibility of faith and reason in order to demonstrate that modern rationalism was the essence of 'true Islām'.

The representatives of the so-called second reform movement or les nouveaux penseurs de l'Isläm in the words of R. Benzine (2004) - have been more radical in their approach to Islām and modernity. 
They constitute a new and very heterogeneous group of intellectuals who find it indispensable to renew the religious discourse through an exhaustive examination and critique of the Qur'ān and turāt. These scholars are determined to introduce a new Qur'ānic hermeneutics, which - with its emphasis on individual liberty in regard to the interpretation of the Qur'ān - constitutes a direct demand for a democratization of the Muslim societies. As such, their demand to study the Qur'ān and turāt according to modern academic standards and to read them as part of human history and not as sacred history have constituted a challenge to both the traditional religious institutions and the dictatorial regimes of their respective countries. Consequently, these scholars have been targets of the ruling powers and the 'ulama', both of whom regard them as a threat to their political and religious hegemony. ${ }^{5}$ Because of their critical approach to the Qur'ān and turāt, these scholars have often been accused of being too influenced by contemporary Western thought. However, though their thinking is characterized by incredulity towards the grand narratives of 'Islām', the modern/postmodern implications of their methodology do not indicate that they directly identify themselves with Western modernism/postmodernism. Their thinking represents an acknowledgement of the methodological and epistemological achievements of Western philosophy as well as a critique of its alleged universality. Operating from the margins of both Western and Islamic academic traditions, they occupy what Homi K. Bhabha has called the 'Third Space' (Bhabha 1994). If we acknowledge the liminal hybridity of their works, it becomes clear that they are more than mere representatives of 'reformist Islām'; the epistemological and methodological underpinnings of their work reveal a critical perspective on Western academia as well.

Thus, on the one hand, there is a qualitative difference between the first and the second reform movement, between a somewhat apologetic approach to the relationship between Islām and modernity, and the critical enterprise of scholars such as 'Abdelmağīd Šarfĩ and Muhammad Arkoun. On the other hand, however, it is my contention that there is a qualitative difference between at least to 'branches' within the so-called second reform movement; between scholars such as Fazlūr Raḥmān (Pakistan), M. Muḥammad Ṭāha (Sudān) and

\footnotetext{
${ }^{5}$ Examples are the Sudanese intellectual M. Muhammad Țāha (1909-85) and the Egyptian professor in Islamic Studies Nașr H. Abū Zayd (1943-2010). Tâha was - in accordance with the regulations of the newly implemented Śarī $a$ law, which he and his followers insisted was repealed - executed in January 1985 after being declared guilty of apostasy, sedition, undermining the constitution, inciting unlawful opposition to the government, disturbing public tranquility, and membership in an unlawful organization. Nașr Ḥ. Abū Zayd, on the other hand, was in 1995 declared guilty of apostasy and consequently declared divorced from his wife because of his academic works on Qur'ānic hermeneutics. He was subsequently forced into exile as he was in danger of being assassinated.
} 
Muhammad Talbī (Tunisia), on the one hand, and, on the other hand, scholars such as Abdolkarīm Sorouš (Irān), 'Abdullāhī An-Na '̄im (Sudān), Naṣr Ḥ. Abū Zayd (Egypt), Muḥammad Arkoun (Algeria), Muhammad 'Ābed al-Ğābirī (Morocco), and 'Abdelmağīd Šarfī (Tunisia). The main reason for grouping these intellectuals into two distinct groups even though they all advocate a hermeneutical approach to the Qur'ān, is that while the first group maintains that the essence of Islām is ethical, and that it is both necessary and possible to distinguish between the historical and the universal aspects of the Qur'ān, the second group rejects the very possibility of this distinction. According to the second group, Islām is plural both in 'essence' and in time.

Thus, what is often defined, as 'reformist' Islām is, in fact, a very heterogeneous group of intellectuals spanning from reformists who ascribe an ahistorical essence to Islām, which is compatible with modernity, to proponents of historical criticism. Along the same line as Filālī-Anșarī, I would, thus, rather characterize the 'second reform movement' as 'enlightened Muslim thought' than reformist (FilaliAnsary 2003). These scholars study the Qur'ān and the manifestations of Islām throughout history by means of modern scientific methodology. By simply labeling them 'reformist' one risks reducing their work to an object of research - 'the Islamic reformist phenomenon' - rather than acknowledging their contributions to the field of research in Islām and entering into a dialogue with them about the proper academic approach to Islām, both in the Muslim world and in the West. ${ }^{6}$ As the Egyptian professor in Islamic Studies, Nașr H. Abū Zayd (1943-2010), has argued, the most important is to gain absolute freedom to pursue critical research within the field of Islamic Studies:

Nous avons besoin de faire librement des recherches dans notre héritage religieux. C'est la condition première du renouveau. Nous devons lever l'embargo sur la pensée libre. La champ du renouveau devrait être illimité. (Cited in Benzine 2004: 24)

(We need to be free to research our religious heritage. This is the first condition of renewal. We must lift the ban on free thought. The field of renewal should be unlimited.)

\footnotetext{
'Abdelmağīd Šarfī

'Abdelmağìd Šarfī has been Professor of Arab Civilization and Islamic Thought, first at the École Normale Superior in Tunis and

${ }^{6}$ Carool Kersten has made a similar point in his study of Nurcholish Madjid, Hasan Hanafi and Muhammad Arkoun in Cosmopolitans and Heretics: New Muslim Intellectuals and the Study of Islām (2011).
} 
then at the University of Manouba (1969-2002). From 1983-86 he was Dean of the Faculty of Arts and Humanities in Tunis. He is a soughtafter speaker and has been visiting professor at several European universities (including Berlin, Paris IV, Lyon II, Rome, and Geneva). He has served as a member of the Council of the Arab Foundation for Modern Thought (2003-2005) and held the Chair of Comparative Religions at UNESCO (1999-2003). He is currently the Director of the collection Ma'àlim al-hadāta (Sud Éditions, Tunis) and is a member of the editorial board of several journals including IBLA (Tunis), Revue Arabe des Droits de l'Homme (Tunis), Islāmochristiana (Rome), and Prologues, Etudes Maghrébines (Casablanca).

Šarfī is the author of numerous internationally acclaimed works including: Al-islām wa-l-ḥadāta ("Islām and Modernity"), Tunis 1990; Al-islām wāḥidan wa muta'addidan ("Islām is one and multiple”), Beirut, 2006-2007; and Al-islām bayn-'l-risāla wa-l-tārīh ("Islām Between Message and History"), Beirut, 2001. The vast majority of his publications is in Arabic and addresses an ArabMuslim educated public. Despite the fact that many friends and colleagues have encouraged him to write in a European language in order to reach the international academia and the majority of Muslims who live in Asia, Europe and The United States and who do not master the Arabic language, Šarfi has chosen to write in Arabic. He insists that Arabic is a living language which can be used to express modern thought, and that it is necessary to convey research in Arabic in order to prevent the Arab public from being alienated from modern science. With this in mind, he has mentored an entire generation of young Tunisian scholars and equipped them with the tools of modern critique.

\section{The Prophetic Message}

Similar to his conception of Arabic as a living language, 'Abdelmağ̄id Šarfi maintains that the Qur'ānic message is not a dead artifact belonging to a museum. On the contrary, Islām is a living religion that addresses the believers in their current situation.

Notre désir de suivre la méthodologie moderne est dû au fait que l'Islām n'est point une religion morte qu'on étudierait comme une pièce de musée. Non, il est une religion vivante que des générations d'anciens ont comprise et pratiquée dans le cadre de conditions historiques et scientifiques déterminées. Ses fidèles d'aujourd'hui se sentent directement concernés par son message, ils attendent d'elle qu'elle réponde à leurs propres interrogations et non pas à celles de leurs pères et de leurs ancêtres, qu'elle leur propose des solutions qui emportent leur adhésion et leur 
engagement, en dehors de toute pression ou contrainte. (Šarfĩ 2004: 18f.)

(I wish to follow modern methodology because Islām is not a dead religion, which can be studied like a museum piece. No, it is a living religion, which earlier generations have understood and practiced in the context of specific historical and scientific conditions. Its followers today feel directly affected by its message; they expect it to answer their own questions and not those of their fathers and their ancestors, to present solutions which they can support and commit to, without pressure or coercion.)

While I am aware that this point has been made by many scholars within the field of Islamic Studies, Šarfî's argumentation is important because he uses the fact that the Qur'ān is a source of continuous inspiration to Muslims to argue for the legitimacy of modern methodology in the study of Islām in contradistinction to Orientalists, such as Arnaldez, and the 'ulam $\bar{a}$ ' who cling to the traditional Islamic disciplines.

Šarfi's conception of the revealed message is, in this context, similar to the Iranian intellectual 'Abdolkarīm Sorouš's (b. 1945) theory of contraction and expansion, which emphasizes the fundamental difference between religion and religiosity (Soroush 2000). Whereas religion remains the same, religiosity (i.e. the interpretations of religion) will constantly change. According to Sorouš, revelation repeats itself every time the Qur'ān is read, and consequently places every reader in the same position as Muhammad. There is a dialectical relation between text and reader. Depending on the existential situation of the reader and the questions, which this situation provokes, the text is understood differently. 'Istām' is not and has never been a uniform entity. Despite the fact that the notion 'Islām' is applied to refer to specific elements which unite the believers and distinguish them from other religious communities and from non-believers, 'Islām' is neither unique in time, place nor in 'essence'. No person can claim that his or her interpretation of 'Islām' is the only correct interpretation as it is a historical fact that the notion 'Islām' has been accommodated to both diverse and contradictory situations throughout its long history (Charfi 2004: 19).

\section{The 'Absolute' as a Historical Phenomenon}

If the hermeneutical relation between text and reader is acknowledged, it becomes necessary to re-examine the nature and functions of those components, which are perceived as the foundation of 'Islām', according to Šarfí. Whereas the institutionalized 
understanding of turăt has given a specific interpretation of the prophetic message precedence over all other interpretations by declaring the former identical with the interpreted text, Šarfi argues that any number of interpretations is possible, as it is impossible to find two identical relations between text and reader.

However, whereas Šarfĩ argues for a hermeneutical approach to the Qur'ān when it comes to the believers' relation to the revealed text, his historical research is rather social constructivist. According to Šarfi, humans have searched for the meaning of their existence throughout history; they have sought to know their origin and destiny and to establish order both within nature and society in order to suppress the chaos of the universe. Man cannot live in a world without order, and he has therefore produced explanations to protect himself against the arbitrary, according to Šarfî. Humans have, for instance, distinguished themselves from animals by introducing culture, which encompasses material as well as moral and ethical developments. In the course of time, culture has obtained autonomy from its human creators, and, oblivious of what they have created and developed, humans have in turn subjected themselves spontaneously to this culture (ibid. 24). Cultures and societies are built upon specific sets of social norms and regulations constructed by man. These norms and regulations exist within all cultures, and their purpose is to distinguish what is permitted from what is prohibited. If this process of socialization succeeds, the norms and regulations become self-evident and illegal to transgress. Moreover, by embracing these rules as if they were autonomous, the individual and the group accept them as faits accomplis neither to be questioned nor subverted. Thus, humans have transcendentalized and sacralized what is in reality a product of their own thinking. According to Šarfī, truth is a human construction which needs to be desacralized and reinstated in its proper historical context.

Similar to Muhammad Arkoun who, by means of his concept 'the imaginary' (l'imaginaire), seeks to determine those concealed mechanisms which transform ordinary events, through symbolic images, into a collective representation which structure our perception of the world (Arkoun 2005: introduction), Šarfi seeks to emphasize that it is the lack of consciousness of this process of transformation which impedes the process of human liberation in the Muslim world. To both Arkoun and Šarfì humans are first and foremost interpreting creatures, which cannot escape their own need to produce images about themselves and others in order to understand themselves and the surrounding world. Historically, religion has played a decisive role in justifying the rules and norms of society, and thus the idées reçues of turāth must be subjected to a historical-critical study that takes into account the socio-cultural setting in which these ideas emerged (ibid. part 1, chapter 4). According to Šarfí, it is impossible to distinguish between the historical and the universal aspects of the Qur'ān. The 
term 'prescription' is a term belonging to Islamic jurisprudence (fiqh), and it is the fuqaha ' (the jurists) who have separated the 'prescriptive' verses of the Qur'ān from their historical context and from the Qur'ān as a whole in order to deduce a divine law (ibid. 68f.). Despite the fact that the Qur'ān reflects the political, social, cultural and economic context in which the prophet lived, the fuqahä' have read the Qur'ān literally as if the latter was trans-historical. Šarfi, by contrast, maintains that the believers, instead of imitating the letter of the Qur'ān, should be obliged to critically reflect upon its content.

In addition to this, Šarfĩ is preoccupied with a critical rereading of the foundation of 'the pillars of Islām' (ibid. 69-74). The intention is not to attack the religious feelings of Muslims, but to address the fact that many Muslims find these rituals outdated. Because the conditions of life have undergone enormous changes since these rituals were codified, many contemporary Muslims find it difficult to live in accordance with them. The question at stake is once again whether Muslims are obliged to follow the practice of their ancestors or free to live as Muslims in accordance with their own convictions (ibid. 73).

According to Šarfī, the ritual regulations in regard to prayer (salāt), charity (zakāt), fast (șawm), and pilgrimage (hăg) are as determined by the historical circumstances as the legal regulations (ahkām fiqhiyya). If we take a look at salāt, for instance, the Qur'ān avoids determining the exact number of prayers, the intention, the state of purity, the ablution, the invocation of Allahhu Akbar (God is great) to mention but a few of the ritual prescriptions concerning salat (ibid. 69f.). Moreover, the codification of the number of prayers is based on a hadīt, which describes Muhammad's night journey and his bargaining with God concerning the number of ritual prayers (Saḥị Buhārī 9:93:608). But as this narrative is based on a mythical mentality, it cannot be given any validity, according to Šarfí. Finally, if the fixation of the time of the prayers in accordance with the hours of the sun, as mentioned in the Qur'ān, is absolute, then the prophetic message does not concern inhabitants of the polar regions in the same manner as it concerns inhabitants of the regions where the length of the day is more or less the same all year.

Šarfi's critical re-reading of the foundations of 'the pillars of Islām' clearly illustrates the difference between the two branches of 'enlightened Muslim thought', as I have described above. Contrary to Šarfī, Fazlūr Raḥmān (1919-1988), for instance, maintained that the number of daily prayers was indisputable.

The five daily prayers are not all mentioned in the Qur'ān, but must be taken to represent the later usage of the Prophet himself, since it would be historically impossible to support the view that the Muslims themselves added two new prayers to the three mentioned in the Qur'ān. (Rahman 1966: 36, cf. 36f. on șawm, 
zakāt, as well as ḥăg).

Thus, whereas scholars such as Šarfī question the very 'essence' of Islām, Fazlūr Raḥmān maintains that Islām has an indisputable essence; but he insists at the same time that the latter must be understood and interpreted in its proper historical context.

The purpose of Šarfï's enterprise is not to abolish 'the pillars of Islām', but to emphasize that the regulations prescribed by the fuqah $\bar{a}^{\text {' }}$ during the formative period of Islām are not absolute. This does not imply that it is wrong to live in accordance with these regulations, merely that there are other means by which to fulfill the religious obligations as a Muslim (Charfi 2004: 71). The believers should, according to Šarfi, be free to regulate the means by which to worship God in accordance with their convictions and worldview.

\section{The Qur'ān as Oral and Written}

In his definition of the prophetic message Šarfī's point of departure is Muhammad 'Abduh's interpretation of revelation in Risālat alTawhìd (The Theology of Unity, 1897). According to Šarfì, 'Abduh understands revelation as the knowledge which man finds within himself being confident that this knowledge is of divine origin (Charfi 2004: 39). If we accept this conception of revelation, the divine choice of Muhammad as a messenger does not exclude his human predispositions, which then, according to Šarfī, necessarily implies that psychological, cultural and social factors have influenced the prophet's knowledge (ibid.). Contrary to the traditionalists who vacillate between an exaltation of the exemplary qualities of the prophet Muhammad and an affirmation that he has received the revelation because of divine choice alone, Šarfi maintains that the one does not exclude the other. Following the intellectual enterprise of Fazlūr Raḥmān, Šarfĩ maintains that the Qur'ān at once is the Word of God and the word of Muhammad.

But orthodoxy (indeed, all medieval thought) lacked the necessary intellectual tools to combine in its formulation of the dogma the otherness and verbal character of the Revelation on the one hand, and its intimate connection with the work and the religious personality of the Prophet on the other, i.e. it lacked the intellectual capacity to say both that the Qur'àn is entirely the Word of God and, in an ordinary sense, also entirely the word of Muhammed. (Rahman 1966: 31)

According to Šarfī, the Qur'ān is the word of God insofar as God is the source, and a human word insofar as it belongs to a particular language, is in conformity with the lexicon and grammar of this 
language, and adjusts to the specific cultural categories of the speaker and his environment (Charfi 2004: 41). In opposition to the Sunnite doctrine of Muhammad's illiteracy (ummiyya) which deprives Muhammad of both his free will and his faculties in order to safeguard the divine nature of the prophetic message, Šarfĩ maintains that the divine and transcendent nature of the Qur'ān can be maintained at the same time as the historical, and consequently relative, character of the latter is emphasized (ibid. 42f.). God has addressed man in a language understood by the latter; otherwise the revealed message would be useless. Moreover, in transmitting the revealed message to his contemporaries the prophet was compelled to use what was at his disposal, and what his contemporaries knew, as well (ibid. 45).

In a similar vein to Arkoun's distinction between the prophetic discourse and the 'Closed Official Corpus' (Arkoun 2006: chapter 1), Šarfì distinguishes between the Qur' ān as an oral message and a written text (Charfi 2004: part 1, chapter 3). There is a qualitative difference between the oral nature of the prophetic discourse and the written codified text.

According to Šarfí, the process of codification has had both positive and negative consequences. Firstly, the political decision of the third Caliph 'Utmān (644-656) to codify the received message in order to bring about unity and to establish absolute power over the state by making the ruling power the sole custodian of revelation is decisive. This decision resulted in a destruction of all non-official collections of the prophetic message, and consequently it has been of great significance for the construction of turät. However, as lamentable as this irreversible process, which has eliminated a large part of the oral prophetic discourse from turāt, might be, it probably prevented the Muslim community from being permeated with religious schisms far worse than the schism between the Sunnites, the Ši 1 ites and the Haariğites after the death of 'Utmān (d. 656), according to Šarfi (ibid. 56). Secondly, the process of codification neither preserved the circumstances nor the intonations of the Qur'annic sūras. Whereas the contemporaries of the prophet Muhammad were not interested in codifying the circumstances of revelation, which they experienced directly, the subsequent generations were. The circumstances of revelation were not codified until two or three generations after Muhammad. Moreover, the intonation of the oral revelation is absent from the written Qur'ān. Contentment, anger, exhortation, reprimand, etc. is something the written word cannot express in the same manner as the intonation of the spoken word. These factors have had the consequence that the written text in opposition to the oral discourse gives rise to a variety of interpretations and, at times, even contradictory interpretations (ibid. 54f.). The conflicting interpretations in turn resulted in a definition of competing orthodoxies, each with the aim of monopolizing the 
authentic interpretation of the text.

Similar to Nașr Ḥ. Abū Zayd, Šarfĩ defines the Qur'ān primarily as an oral discourse and only secondarily as a written text. The difference between understanding the Qur'ān as discourse and as text is, however, not purely a difference between the oral and the written. Contrary to a hermeneutical approach to the Qur'ān, discourse analysis is preoccupied with the relation between language, power and truth. That is, the Qur'ān is not only a text to be read and analyzed; it is both a product of an original oral discourse and an orally recited discourse, which shapes the lives of the believers. Whereas the production of the written text was the first step towards institutionalization and orthodoxy, understanding the Qur' ān as an oral discourse emphasizes that the Qur'ān is a living phenomenon, which, both past and present, is the outcome of dialogue, debates, disputes, acceptance and rejection. Abū Zayd's interpretation of the horizontal dimension of the Qur'ān in Rethinking the Qur'ān: Towards a Humanistic Hermeneutics (2004) is a perfect example of this. If the horizontal dimension of the Qur' ān is to be acknowledged, it is necessary to understand the Qur'ān as discourse rather than text, according to Abū Zayd. Whereas the Qur'ān understood as text reduces the former to a corpus open to ideological manipulation, the Qur'ān understood as discourse emphasizes the status of the recited Qur'ān in shaping the public consciousness (Abu Zayd 2004: 10). According to Abū Zayd, applying modern hermeneutics in relation to the Qur'ān - as rewarding as it might be - disregards the diverse cultures and convictions of the masses and has led both traditionalists and reformists to produce authoritative hermeneutics. Contrary to the interpretation of the Qur'ānic text by the elite, which is often affected by power manipulations, the living status of the Qur'ān as discourse enhances a democratically open hermeneutics.

\section{Muhammad as 'the Seal of the Prophets'}

According to the Qur'ān (33:40), Muhammad is the last prophet, and his message seals the prophetic traditions. Consequently, the decisive question is whether this sealing signifies a deadlock or emancipation. Does the sealing indicate a fixation of a set of untouchable rules and regulations, or does it liberate humankind from all sorts of fixation in order to introduce a new space within which man has to take responsibility for his actions? To illustrate these two possible interpretations of 'the seal of the prophets', Šarfi applies the picture of locking the door of one's house either from the inside or the outside (Charfi 2004: part 1, chapter 5). If the door is locked from the inside, as the sealing traditionally is understood, then man is imprisoned in a definitive fixation of those concepts and prescriptions which have been revealed through the last prophetic message. The possibility of 
evolution, progress and innovation is dismissed. God's command can, then, only be observed if the Qur'ān is read literally and as an ahistorical message.

If the door, on the other hand, is locked from the outside, the sealing indicates a closure in regard to the human need to seek aid from and comfort in fixed norms and regulations.

En ce sens, le fait de sceller pose une limite à la nécessité pour l'homme d'appuyer sa connaissance sur une source et sa conduite sur une norme extérieure. Il annonce à toute l'humanité l'inauguration d'une ère nouvelle, d'une nouvelle étape de l'histoire où l'homme, ayant atteint la maturité, n'aura plus besion d'un guide ou d'un tuteur pour les moindres details de son existence. (Ibid. 100)

(In this sense, the act of sealing sets a limit to the need for man to base his knowledge on a source and his acts on an external norm. It announces to all humanity the inauguration of a new era, a new stage in history, where man, having reached maturity, no longer needs a guide or tutor to every detail in his life.)

Indeed, if the sealing is understood in this way, the mission of Muhammad as the last prophet is to guide man towards his new responsibility. If the door to 'the house of prophecies' is locked from the outside, man is free to meet the challenges of the world. The objective of the seal is then to liberate man, not to imprison him by forcing him to imitate the example of the prophet as the traditionalists claim. Liberation is at the core of the prophetic message, and true liberation can only be obtained if the idées reçues are constantly questioned. As such, the sealing constitutes an opening towards a vast number of horizons within which man is free to organize his existence and responsible for his acts (ibid. 103).

\section{Institutionalization}

If it is possible to interpret 'the seal of the prophets' as an act of emancipation, a question comes to mind: Why has this interpretation not determined the reception of the prophetic message throughout history? One of the primary factors regarding Islām, according to Šarfì, is that diversity at the time of Muhammad and the subsequent generations was conceived as everything but fruitful (ibid. 134). Supported by this mistrust of diversity the process of institutionalization had favorable conditions. However, the institutionalization of Islām is not a unique phenomenon. Institutionalization is an inescapable process for all movements whether religious or non-religious - as the need to create order 
through rules and regulations is a conditio sine qua non for man. As such, the objective of Šarfî's critique of 'institutionalized Islām' equals Arkoun's critique of 'orthodox Islām'. The process of institutionalization has diverted the original form of the prophetic message - an oral discourse which is both shaped by and continuously shaping dialogue, debate, and dispute - and as such it has created vast areas of the unthought and the unthinkable, to use the terminology of Arkoun (Arkoun 2006: introduction).

The purpose of institutionalization is to control the transformation from theory to practice, and as such the process of institutionalization takes place on multiple levels (Charfi 2004: part 2, chapter 2). Firstly, through confessionalism institutionalization constitutes a contributory factor in the distinction between Muslim and non-Muslim communities. As Muslims represented a minority at the emergence of Islām, this is not surprising. Confessionalism was, among other things, a means by which to distinguish the new religion from the established religions and communities at the time. In order to ensure that existing religions and communities did not absorb the adherents of the new religion, doctrines, rites, prescriptions and prohibitions were introduced. Specific clothes, food and social conventions were means by which to make it easier to recognize one another.

Secondly, institutionalization constitutes a formalization of rituals (ibid. 133f.). The different forms of practice were transformed into uniform rituals eliminating personal initiative, and consequently the possibility of deviating from the established, sacralized and unchangeable principles. The original flexibility of the message was abolished in favor of an obligatory practice. Rituals, which at the time of prophet Muhammad were changed, depending on the circumstances, became immutable in order to safeguard the unity of the community. In time, ritualism became a more and more mechanical practice at the expense of its initial signification and caused the believers to blindly submit to the external requirements without inner conviction.

Thirdly, and in continuation of the first two manifestations of institutionalization, the prophetic message was transformed into an institution, which continuously has formulated binding dogmas. This dogmatization of the Muslim faith was based on a literal reading of the Qur'an with the objective of enumerating a number of truths, which Muslims were obliged to believe in. In order to maintain their position as representatives of the official religious institution, the dominating class gradually eliminated the possibility of free and contestatory thinking (ibid. 137).

These three procedures comprise a process of transcendentalization and sacralization, which all messages, religious as well as non-religious, must bear. But because Muslims have had difficulties liberating themselves from these sacralized norms and 
regulations, they have been impeded from being the pioneers in regard to human rights etc. Similar to his compatriot, professor of private law, the former President of the Tunisian League for Human Rights, and former Minister of Education, Muhammad Šarfī, 'Abdelmağīd Šarfi emphasizes that what initially constituted progress and a step towards liberty and equality, has resulted in stagnation because the Šarīa law, though a human creation, has been absolutized and sacralized.

Compared with earlier or contemporaneous bodies of law, Muslim law represented a general advance in human history with regard to the rights of non-Muslims, slaves and women, a considerable step towards liberty and equality and hence towards the foundations of human rights as we conceive them today. The sharia is a set of laws which appear unjust by the standards of today. But the 'ulamā' who drew them up were chained to the circumstances of their time. (Charfi 2005: 79)

\section{A Qur'ānic Ethics}

'Abdelmağ̄id Šarfì's focus on a Qur'ānic spirit of liberation has clear ethical implications. In this regard, his intellectual enterprise is somewhat similar to that of Fazlūr Raḥmān and M. Muḥammad Ṭāha who maintain that the essence of Islām is ethical. However, Šarfī's conception of a Qur'ānic ethics provides some basis for a nonessentialist view. In the remaining part of the paper, I will try to explain the difference between the two conceptions of a Qur'ānic ethics.

The essence of M. Muhammad Țāha's intellectual enterprise is a distinction between the Meccan and the Medinese sūras. Whereas the prophetic message during the Mecca period was addressed to the whole of humanity, it was restricted to the contemporaries of the prophet during the Medina period, according to Taha. In opposition to the 'ulama', Taha concluded that if there is a contradiction between two verses in the Qur'ān, the Meccan verse should take precedence over the Medinese. Though Taha, according to both 'Abdelmağìd Šarfī and Muhammad Šarfī, was correct in his interpretation of the difference between the Meccan and the Medinese sūras, and in his emphasis on freedom and equality throughout his interpretation of the Qur'ān, his emphasis on the universal and eternal nature of the Meccan sūras is an expression of a modern essentialism which risk solving one problem while creating another.

Furthermore, the theory of hermeneutics and the idea of a distinction between the eternal and the specific verses share the drawback that they risk solving one problem while creating another in its stead. It is true that Taha tends to be more explicative and Talbi 
more normative. But both writers argue for one religious body of law to be replaced with another religious body of law. This is an important drawback of their writing. (Ibid. 97f.)

Both 'Abdelmağīd Šarfĩ and Muḥammad Šarfĩ maintain, in a way comparable to that of Arkoun, that the distinction between the eternal and the specific, as seen in the writings of several Muslim modernists, is an expression of an 'ahistorical' reading of the Qur' ān.

Abdelmajid Šarfî's social constructivist reading of the Qur'ān and the Islamic tradition constitutes a 'postmodern' perspective on the deficiencies of modern Muslim intellectuals' methodology. In this respect, his intellectual enterprise has several features in common with the Canadian philosopher Charles Taylor's critique of modernity (1992). Similar to Taylor's diagnosis of the malaise of modernity where a common ethics and a common horizon of meaning have been replaced by individualism and the precedence of instrumental reason, Šarfi points towards the fact that behind absolute freedom lies hidden the constant possibility of an immoral world.

Toutefois, derrière cette liberté absolue, se cache la possibilité d'un monde amoral, guide uniquement par l'intérêt immediate; c'est là une conséquence qu'il ne faut pas fuir ni masquer par quelque subterfuge.

Ici intervient le role de l'ethique coranique qui, comme la liberté et avec elle, est un horizon indépassable. Le croyant n'est pas guide par une lumière qui transcenderait l'histoire: il chemine dans une lumière qui remplit l'univers et qui donne le moyens de réfléchir sur l'existence et sur le monde. (Šarfĩ 2004: 216)

(However, behind this absolute freedom, lies the possibility of an amoral world, only guided by immediate interest, hidden; this is a consequence which we should not flee or disguise by any subterfuge. Here the role of the Qur'ānic ethics intervenes, which, like freedom and with it, is an unsurpassable horizon. The believer is not guided by a light which transcends history: he walks in a light which fills the universe and which provides him with the means to reflect on life and the world.)

As the Qur'ānic ethics, like liberty, constitutes an inexceedable horizon for Muslims, absolute liberty does not endanger morality, according to Šarfī. However, Šarfì's emphasis on a Qur'ānic ethics does not indicate that he promotes a return to a traditional understanding of religion or a religious justification of the solidarity between individuals. Similar to Charles Taylor who substitutes traditional relations of solidarity with an inter-subjective horizon of values, Šarfi's emphasis on the ethical aspects of the Qur'ān must be seen in the context of his critique of turāt:

Mais la solidarité entre les individus s'est aujourd'hui établie sur 
des bases nouvelles qui n'ont pas besoin de justification religieuse, ce qui a provoqué, au cours des deux derniers siècles, une contestation de fait des formes traditionelles de la piété. La conséquence de cette situation sans précédent, c'est que les religions institutionelles ont été dépossedées, à leur corps défendant, de leur rôle traditionnel, sous la pression conjuguée et irrésistible de la réalité et de la pensée modernes. (Ibid. 213)

(But today solidarity between individuals is established on new bases which do not need religious justification; a fact which, over the last two centuries, has challenged the traditional forms of piety. The consequence of this unprecedented situation is that the institutional religions, against their will, have been dispossessed of their traditional role by the combined and irresistible pressure of reality and modern thought.)

The main objective of introducing Qur' ānic ethics as an inexceedable horizon is to underline the fact that neither the Qur'ān nor Islām is a dead artifact belonging to a museum. Indeed, notwithstanding institutionalized Islām, the Qur'ān is perceived as a living text that addresses the believers in their current situation. Thus, according to Šarfi the Qur'ān is a text to be appropriated by the believers, and this appropriation can take place in infinite ways. It encourages the believer to reflect on the norms of society and the relation between good and evil without providing any ready-made solutions.

\section{Conclusion}

'Abdelmağīd Šarfī's reading of the prophetic message as discourse rather than text, his interpretation of 'the seal of the prophets' and his conception of a Qur'ānic ethics of liberation reveals an intellectual enterprise that is highly engaged and committed. Šarfī writes in Arabic to an Arab-Muslim reader with the explicit goal of challenging the traditional Islamic disciplines and methodologies. As such, his academic work could be labeled 'reformist'. On the one hand, he seeks to introduce a new hermeneutics to present-day Muslims which acknowledges the living status of the Qur'ān in the lives of the believers while emphasizing that Islām is neither unique in time, place or in 'essence'. Whereas Šarfi proposes that the prophetic message is read as an act of emancipation which to him reflects individual liberty, human rights and democracy, he is aware that no person, including himself, can claim that his or her interpretation of 'Islām' is the only correct interpretation as it is a historical fact that the notion 'Islām' has been accommodated to both diverse and contradictory situations throughout its long history.

Seen from another perspective, however, his academic work is 
more than a mere 'reformist' project. The epistemological and methodological underpinnings of his work do not simply challenge the traditional Islamic disciplines; they reveal a critical perspective on the field of Islamic Studies in general as well. How do we adequately approach the Qur'ān and the reception of it throughout history? Whereas Islamic Studies have been dominated by philological, historical analyses of the most 'representative' texts, on the one hand, and social scientific research with primary focuses on more 'shortterm' socio-political issues, on the other hand, scholars, such as Šarfi and Arkoun, propose a multidisciplinary approach to the field. With primary focus on philosophy, literary theory and postcolonial criticism they seek to challenge any transference of taqlid (imitation) to modern scholarship where "'Islām' is constructed as a substantial, unified and unifying body of beliefs, non-beliefs, institutions, customs, stabilized theological, legal and ethical doctrines, recurrent practices and representations." (Arkoun 2006: 225).

\section{Author biography:}

Tina Dransfeldt Christensen is Ph.D. Fellow at Cultural Encounters, Roskilde University. Her publications include: "Narrating the Unnarratable: The Role of Literary Memory in Moroccan Testimonial Writing" (Madrid: EURAMAL publication, forthcoming), "Ny marokkansk literatur: Abdellah Taïa og den homoerotiske roman" (FranskNyt 263, 2012), and Mohammed Arkoun: Den arabiske tænkning (København: Forlaget Gramma, 2009).

\section{References}

Abu-Rabi', Ibrahim M., 2003: Contemporary Arab Thought, Studies in post-1967 Arab Intellectual History. Pluto Press, London/Sterling, Virginia.

Abu-Zayd, Nasr Hamid, 2004: Rethinking the Qur'ān. Towards a Humanistic Hermeneutics. Humanistics University Press, Utrecht.

Arkoun, Mohammed, 2005: Humanisme et Islām: Combats et propositions. Vrin, Paris.

Arkoun, Mohammed, 2006: Islam: To Reform of to Subvert? Saqi Essentials, London.

Arnaldez, Roger, 2002: L'homme selon le Coran. Hachette Littérature, Paris.

Benzine, Rachid, 2004: Les nouveaux penseurs de l'Islam. Albin 
Michel, Paris.

Bhabha, Homi K., 1994: The Location of Culture. Routledge, New York.

Binder, Leonard, 1988: Islamic Liberalism: A Critique of Development Ideologies. Chicago: The University of Chicago Press.

Charfî, Abdelmajid, 2004: L'Islam entre le message et l'histoire. Albin Michel, Paris.

Charfi, Mohamed, 2005: Islam and Liberty. The Historical Misunderstanding. Zed Books, London/New York.

Filali-Ansary, Abdou, 2003: "What is Liberal Islam? The Sources of Enlightened Muslim Thought," in: Journal of Democracy, vol. 14, num. 2.

Kersten, Carool, 2011: Cosmopolitans and Heretics: New Muslim Intellectuals and the Study of Islam. Columbia University Press, New York.

Lee, Robert, 1997: Overcoming Tradition and Modernity: The Search for Islamic Authenticity. Boulder: Westview Press.

Rahman, Fazlur, 1966: Islam. University of Chicago Press, Chicago.

Soroush, Abdolkarim, 2000: Reason, Freedom, and Democracy in Islam. Oxford University Press, Oxford.

Taylor, Charles, 1992: The Ethics of Authenticity. Harvard University Press. 